Article

\title{
Responses of Soil Seed Bank and Vegetation to the Increasing Intensity of Human Disturbance in a Semi-Arid Region of Northern China
}

\author{
Cui $\mathrm{Li}^{1}{ }^{(\mathbb{D})}$, Bo Xiao ${ }^{2}$, Qinghai Wang ${ }^{1, *}$, Ruilun Zheng ${ }^{1}$ and Juying $\mathrm{Wu}^{1}$ \\ 1 Research and Development Center for Grass and Environment, Beijing Academy of Agriculture and Forestry \\ Sciences, Beijing 100097, China; biolicui@163.com (C.L.); rlzheng@163.com (R.Z.); wujuying@263.com (J.W.) \\ 2 Department of Soil and Water Sciences, China Agricultural University, Beijing 100193, China; \\ xiaobo@cau.edu.cn \\ * Correspondence: qinghaiw@sina.com; Tel.: +86-010-5150-3436
}

Received: 5 September 2017; Accepted: 1 October 2017; Published: 12 October 2017

\begin{abstract}
To provide more insights into the responses of the soil seed bank and vegetation to human disturbance intensity, we selected four land use types, including: native grassland (no human disturbance), abandoned artificial grassland (light human disturbance), artificial grassland (moderate human disturbance), and farmland (severe human disturbance) in a semi-arid climate of northern China. The species composition and density of the soil seed bank were measured, as well as the species composition and amount of vegetation. The native grassland had a significantly higher soil seed density and species richness than the other land use types. Moreover, the common species both in the soil seed bank and vegetation between the native grassland and other land use types gradually decreased as disturbance intensity increased. The abandoned artificial grassland and artificial grassland still had abundant soil seed banks according to their seed density $(\geq 28.2 \%$ of the native grassland) and species richness ( $\geq 70.0 \%$ of the native grassland) to restore the vegetation. Conversely, it was hard to restore the vegetation on the farmland due to its low soil seed density (10.0\% of the native grassland) and species richness ( $40.0 \%$ of the native grassland). In conclusion, human disturbance would generate significant negative effects on the soil seed bank in desertified regions in a semi-arid climate; however, the soil seed bank in land use types with light/moderate disturbance are more adapted to vegetation restoration compared with land use types with severe disturbance in a semi-arid region.
\end{abstract}

Keywords: soil seed bank; disturbance intensity; species richness; seed density; vegetation restoration

\section{Introduction}

Desertification due to climate change and human activities in arid and semi-arid climate regions has become one of the most important global issues because of its adverse impacts on agricultural productivity, food security, environment, and quality of life [1]. It has been reported that desertification affects $1.5 \times 10^{9}$ people globally, which accounts for $74 \%$ of the poor throughout the world [2,3]. In China, it totally affects more than $4 \times 10^{8}$ people and $2.6 \times 10^{6} \mathrm{~km}^{2}$ of land $[4,5]$. Due to the dramatic decreasing of soil quality in desertified land, especially in soil water and nutrients, the degradation of vascular plants and the irreversible rapid decrease of vegetation cover become the most important characteristics of desertification. In the past decades, trees and shrubs planting were traditionally employed to restore vegetation and combat desertification in North China [6], but it did not perform very well, mainly due to its high cost, low survival rate, and high water consumption [7]. A nature-based solution was considered as a cost-effective long-term solution for land degradation; it focused on improving soil quality and restoring vegetation to enhance the 
sustainability of the degraded land [8]. Soil seed bank has been considered as a promising method for restoring vegetation [9], but its influencing factors have not yet been fully understood [10].

Soil seed bank is defined as the viable seeds that exist on the soil surface or buried in soil [11], which represents the memories of the last plant community and the development of a future plant community in the surrounding area [12]. It is generally considered that the soil seed bank is the seed resources of native vascular plants, and would supply most seedlings for vegetation regeneration [13]. Thus, the soil seed bank plays critical roles in restoring degraded vegetation and ecosystem in desertification regions $[14,15]$. However, the feasibility of vegetation restoration using the soil seed bank is largely dependent on its seed density [16] and species composition. For example, it was reported that the soil seed bank was sufficient to restore degraded vegetation in the Hunshandak Sandlands in northern China due to enough seeds in the soil [17], while in northeastern Hungary it was not viable to restore degraded vegetation with only the natural soil seed bank due to the lack of native species [18]. It has been proven that many factors could affect the seed density and species composition, such as seed size and shape [19], historical vegetation [20], microhabitat variation [21], human disturbance [22], season variation [23], and climate changes [24]. Many studies have been conducted in recent years that attempt to understand the effects of human disturbance on the soil seed bank [25,26]. However, most of these studies focused on the type of disturbance, including land utility [27], grazing [28], and animal eating and footing [29], rather than the intensity. Some studies reported that soil seed density possibly increased [30] or decreased [31] with increasing intensity of human disturbance, but this problem has not yet been fully investigated. Thus, further studies are necessary to determine the effects of disturbance intensity on the soil seed bank.

In this study, the responses of the soil seed bank and vegetation to human disturbance intensity were studied through field investigations and seed germination experiments in a desertified region in a semi-arid climate of North China. In order to illustrate the influence of disturbance intensity on the soil seed bank and vegetation, and evaluate the restoration potential of the soil seed bank, we calculated seed density/number of planting, species composition, and species richness of the soil seed bank and vegetation and analyzed the relationship between the soil seed bank and vegetation. The results would be helpful for vegetation restoration and desertification control in semi-arid regions of North China, and in similar regions all over the world.

\section{Materials and Methods}

\subsection{Study Area}

The study was conducted in the Kangzhuang area $\left(40^{\circ} 19^{\prime} \mathrm{N}\right.$ and $\left.115^{\circ} 43^{\prime} \mathrm{E}\right)$, which is a desertified region in Beijing, North China. This region has a continental monsoon climate with an annual average temperature of $2-8{ }^{\circ} \mathrm{C}$. The average annual precipitation and potential evaporation are 386.2 and $1652.3 \mathrm{~mm}$, respectively [32]. Drought is followed by concentrated rainfall, sparse vegetation, loose soils, and frequent strong winds in winter and early spring, and inappropriate land-use practices in history have resulted in severe wind erosion and desertification in this region. The dominant soil in this region is fluvo-aquic soil (cambisols in FAO soil classification) and cinnamon soil (luvisols in FAO soil classification), while the main soil texture is sandy loam and loamy sand.

\subsection{Experimental Design and Measurement}

We selected four land use types, including native grassland, abandoned artificial grassland, artificial grassland, and farmland, to represent different human disturbance intensities, i.e., no disturbance, light disturbance, moderate disturbance, and severe disturbance, respectively.

The four land use types were all historically native grassland. The native grassland had not been used for more than 20 years. In the artificial grassland, the native grassland was reclaimed, and then alfalfa (Medicago sativa) was planted in 2000 . The seeding rate was $18 \mathrm{~kg} \mathrm{hm}^{-2}$, and row space was $25 \mathrm{~cm}$. Since then, $750 \mathrm{~kg} \mathrm{hm}^{-2}$ of fertilizer (N 5\%, P 15\%, K 15\%) was applied 
every year, and the alfalfa was harvested three times a year. In the abandoned artificial grassland, the alfalfa grassland that had been planted for six years was abandoned (all management practices were stopped) in 2006. In the farmland, maize (Zea mays L.) was produced on the reclaimed native grassland in 2000 through conventional tillage practices, including deep ploughing $(>30 \mathrm{~cm})$, manual weed control, the usage of herbicide and fertilizer, and rain-fed irrigation. The seeding rate was $26 \mathrm{~kg} \mathrm{hm}^{-2}$, row space was $50 \mathrm{~cm}$, and $750 \mathrm{~kg} \mathrm{hm}^{-2}$ of fertilizer (N 26\%, P 10\%, K 12\%) was applied every year before sowing. According to the above description, the disturbance intensity of the four land use types was regarded as native grassland $<$ abandoned artificial grassland $<$ artificial grassland $<$ farmland.

According to the experimental design, a representative sampling region of $15 \mathrm{~m} \times 15 \mathrm{~m}$ was chosen in every land use type. Five replicated $1 \mathrm{~m} \times 1 \mathrm{~m}$ sampling sites were randomly selected. The soil at $0-5$ and 5-10 $\mathrm{cm}$ depths around the selected sampling sites was taken with an auger $(10 \mathrm{~cm}$ in diameter) through the five-point (quincunx-shaped) sampling method in late March 2014. The soil samples (40 in total) were taken back and sieved out through a 2-mm screen to remove concretes and plant debris. Each sample was placed in a plastic germination tray $(40 \mathrm{~cm} \times 25 \mathrm{~cm} \times 10 \mathrm{~cm})$ with $3 \mathrm{~cm}$ depth of sterilized sand at the bottom. The sterilized sand, which was dried for $24 \mathrm{~h}$ at $130{ }^{\circ} \mathrm{C}$, was used as the control to indicate airborne contamination. The soil seed bank, including the number of soil seed and species, was recorded for all of the samples through the germination method in a plant growth chamber [33]. During the experiments, the samples were watered every day to keep sufficient soil moisture. The emerging seedlings in each sample were identified and removed; and their species and number were recorded. The samples were turned over when there was no new germinating seedling after 10 days to make sure that all of the soil seeds had been germinated. The germination experiments were stopped after about five months. According to the recorded species name and number, the seed density and species richness of soil seed bank were calculated for the four land use types. The plant community of the aboveground vegetation, including the species name and number, was investigated through five replicated random quadrats $(1 \mathrm{~m} \times 1 \mathrm{~m})$ around each sampling site of soil seed bank in August 2014, when the vegetation flourished.

\subsection{Data Analyses}

The experimental data were analyzed by SPSS Statistics 22.0. The final results of each land use type resulted from the mean values of the five replicates, and were expressed as mean $\pm \mathrm{SE}$. The differences in the soil seed bank and vegetation among the four land use types were evaluated at $p<0.05$ level by the one-way ANOVA and multiple comparisons (LSD test). The numbers of seeds were $\log (x+1)$ transformed prior to statistical analyses to satisfy the homogeneity of variance assumption. The DCA (detrended correspondence analysis) was conducted by CANOCO 5.0 to further compare the species composition of the soil seed bank and vegetation in the four land use types. The species richness was calculated from the number of one species divided by the number of total species in each sample (one plot for the soil seed bank and one quadrat for vegetation). Dominance was calculated with relative density and relative frequency.

\section{Results}

\subsection{Soil Seed Bank in the Four Land Use Types}

We identified 54 species in total from the soil seed banks of the four land use types, which belong to 21 families and 40 genuses. Most of these species were Compositae (21.6\%), Poaceae (19.6\%), and Chenopodiaceae (9.8\%); and the 54 species were composed of $66.7 \%$ of annuals and $33.3 \%$ of perennials. The number of the identified species from the soil seed bank of the native grassland, abandoned artificial grassland, artificial grassland, and farmland was 37, 29, 26, and 18, respectively. The dominant species were Artemisia capillaris Thunb., Potentilla supina L., and Setaira viridis (L.) Beauv. in the native grassland; Artemisia capillaris Thunb., Artemisia lavandulaefolia DC, and Artemisia annua L. in the abandoned artificial grassland; Artemisia capillaris Thunb., Artemisia lavandulaefolia DC, and Salsola collina Pall. in the artificial 
grassland; and Amaranthus retroflexus L., Salix matsudana L., and Chenopodium aristatum L. in the farmland (Appendix A). The proportions of annuals in each of the four land use types (native grassland $67.5 \%$; abandoned artificial grassland 62.1\%; artificial grassland 61.5\%; farmland 83.3\%) were all higher than the proportions of perennials. Moreover, the numbers of annuals and perennials both gradually decreased with increasing disturbance intensity.

As listed in Table 1, the soil seed density significantly decreased as disturbance intensity increased. The differences of the soil seed density between every two land use types were significant $(\mathrm{F}=14.24$, $p<0.001)$ in most cases. The soil seeds in abandoned artificial grassland and artificial grassland were more than $28.2 \%$ of the native grassland. But in farmland, only $10 \%$ of seeds were native grassland. Furthermore, the soil seed density at $0-5 \mathrm{~cm}$ soil depth was $76.5 \%, 79.7 \%, 69.6 \%$, and $59.2 \%$ of the total at $0-10 \mathrm{~cm}$ soil depth in the four land use types, respectively. The results indicated that the seed density both in the upper soil and deeper soil gradually decreased with increasing disturbance intensity. Also, the soil seed density at $0-5 \mathrm{~cm}$ soil depth was significantly ( $\mathrm{F}>6.31, p<0.05$ ) higher than that at $5-10 \mathrm{~cm}$ soil depth in all of the land use types, with the exception of the farmland. The species richness of the soil seed bank also decreased with increasing disturbance intensity. The decrease was significant $(\mathrm{F}=16.40, p<0.001)$. Compared with native grassland, there were still more than $69.6 \%$ species in the artificial grassland. However, it were only $39.2 \%$ of the species in the farmland.

Table 1. Seed density and species richness of the soil seed banks in the four land use types.

\begin{tabular}{cccccc}
\hline Seed Bank Characteristics & Soil Depth $(\mathbf{c m})$ & $\begin{array}{c}\text { Native } \\
\text { Grassland }\end{array}$ & $\begin{array}{c}\text { Abandoned } \\
\text { Artificial } \\
\text { Grassland }\end{array}$ & $\begin{array}{c}\text { Artificial } \\
\text { Grassland }\end{array}$ & Farmland \\
\hline \multirow{2}{*}{ Seed density $\left(\mathrm{seed} / \mathrm{m}^{2}\right)$} & $0-5$ & $8428 \pm 1585 \mathrm{a}$ & $4710 \pm 2030 \mathrm{ab}$ & $2162 \pm 100 \mathrm{~b}$ & $654 \pm 409 \mathrm{c}$ \\
& $5-10$ & $2596 \pm 292 \mathrm{a}$ & $1202 \pm 378 \mathrm{ab}$ & $944 \pm 230 \mathrm{~b}$ & $450 \pm 245 \mathrm{c}$ \\
& Total & $11,024 \pm 1857 \mathrm{a}$ & $5912 \pm 2393 \mathrm{ab}$ & $3106 \pm 272 \mathrm{~b}$ & $1104 \pm 650 \mathrm{c}$ \\
\hline \multirow{2}{*}{ Species richness } & $0-5$ & $17 \pm 1 \mathrm{a}$ & $11 \pm 2 \mathrm{~b}$ & $12 \pm 1 \mathrm{~b}$ & $6 \pm 1 \mathrm{c}$ \\
& $5-10$ & $14 \pm 1 \mathrm{a}$ & $11 \pm 1 \mathrm{ab}$ & $8 \pm 1 \mathrm{bc}$ & $5 \pm 2 \mathrm{c}$ \\
& Total & $20 \pm 1 \mathrm{a}$ & $15 \pm 1 \mathrm{~b}$ & $14 \pm 1 \mathrm{~b}$ & $8 \pm 2 \mathrm{c}$ \\
\hline
\end{tabular}

Note: Different letters in the same row indicate significant difference at $p<0.05$ level.

\subsection{Vegetation in the Four Land Use Types}

We found 38 species in total in the aboveground vegetation, which belonged to 15 families and 32 genuses. The vegetation was composed of Poaceae (34.2\%), Compositae (21.1\%), and Leguminosae (7.9\%); and the proportion of annuals and perennials were $31.6 \%$ and $68.4 \%$, respectively. The number of the identified species from the vegetation of the native grassland, abandoned artificial grassland, artificial grassland, and farmland was 20,17, 14, and 6, respectively. The proportion of perennials in the native grassland was higher than annuals, while in the artificial grassland and abandoned artificial grassland the proportion of annuals was higher than the proportion of perennials. These results indicated that human disturbance reduced the number of perennial plants, and increased the number of annual plants.

Species richness in the vegetation of the four land use types was native grassland $(9 \pm 1)>$ abandoned artificial grassland $(8 \pm 2)>$ artificial grassland $(6 \pm 0)>$ farmland $(2 \pm 0)$. We observed a significant $(\mathrm{F}=13.07, p<0.001)$ decrease of species richness in the vegetation with disturbance intensity, especially from artificial grassland to farmland. Moreover, the native grassland had the largest number of plants $\left(470\right.$ plant $\left./ \mathrm{m}^{2}\right)$, whereas the farmland had the smallest number of plants $\left(14\right.$ plant $\left./ \mathrm{m}^{2}\right)$. The total number of plants in the vegetation of the native grassland was 2.24, 1.63, and 33.57 times $(\mathrm{F}=4.19, p<0.001)$ that of the abandoned artificial grassland, artificial grassland, and farmland, respectively.

\subsection{Relationship between Soil Seed Bank and Vegetation}

The samples of the different disturbance intensity were separated by the first axis of the ordination plot. The values for the first DCA axis were 0.97 . The high values indicated that the first axis had 
the most variations. This is confirmed by the value of axis1, which differed significantly among different disturbance intensities $(\mathrm{F}=14.89, p<0.01)$. In Figure 1 , the soil seed bank of the farmland was far away from the others; whereas the soil seed bank of the native grassland, abandoned artificial grassland and artificial grassland had mostly overlapped each other. The results implied that there were close relationships among the soil seed banks of the native grassland, abandoned artificial grassland, and artificial grassland. However, the result of the vegetation presented in Figure 1 greatly differed from that of the soil seed bank. Except for the abandoned artificial grassland and artificial grassland, the species composition in the vegetation of the four land use types were far from each other, indicating that the relationships of the vegetation among the four land use types were not as close as that of the soil seed bank, especially for the native grassland and farmland. In Figure 1, the distance between the soil seed bank and vegetation in native grassland, alfalfa grassland, and abandoned artificial grassland were similar and less than that in the farmland. Further, the soil seed bank of the farmland was far away from the vegetation, implying that the variation of species composition between the soil seed bank and vegetation was greatest in severe disturbance intensity.

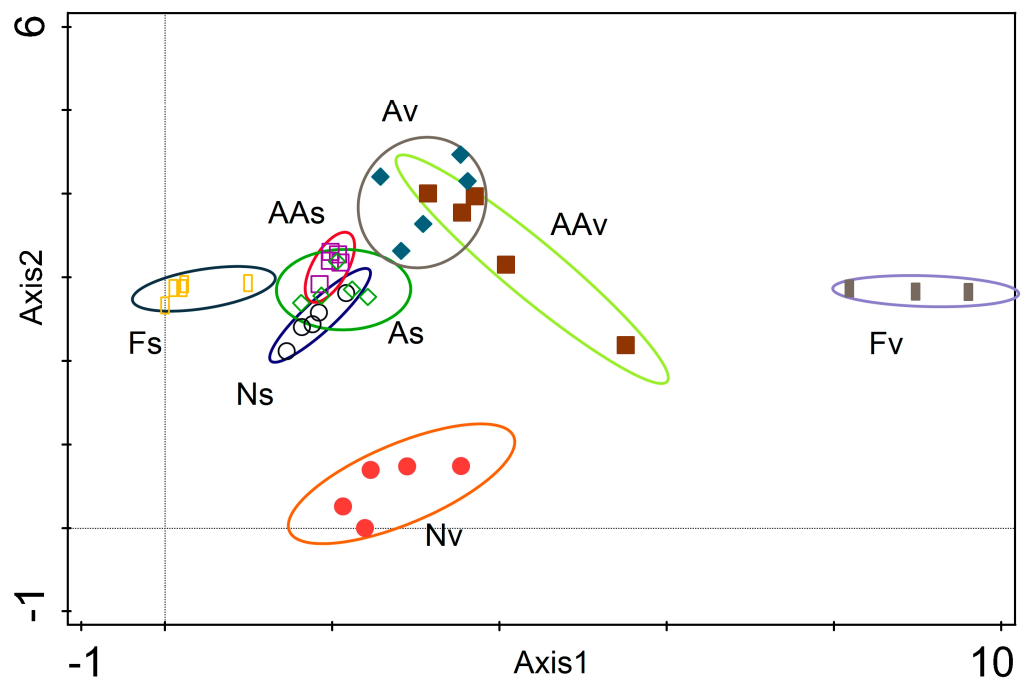

Figure 1. Detrended correspondence analysis (DCA) of species composition in the soil seed bank $(n=20)$ and vegetation $(n=20)$ of the four land use types. Ns, soil seed bank in the native grassland; $\mathrm{Nv}$, vegetation in the native grassland; AAs, soil seed bank in the abandoned artificial grassland; $\mathrm{AAv}$, vegetation in the abandoned artificial grassland; As, soil seed bank in the artificial grassland; $A v$, vegetation in the artificial grassland; Fs, soil seed bank in the farmland; Fv, vegetation in the farmland.

From Figure 2, we can see that the amount of species recorded in the vegetation were lower than that in the seed bank. In native grassland, 20 species were found in the vegetation, which was nearly half of the species number recorded in the seed bank. There were 12 common species between the seed bank and the vegetation; there were eight species that were only recorded in the vegetation and 25 species that were only recorded in the seed bank. In the abandoned artificial grassland, there were nine common species between the soil seed bank and vegetation, eight species recorded only in the vegetation, and 19 species recorded only in the seed bank. In the artificial grassland, there were nine common species, four species only recorded in the vegetation, and 17 species recorded only in the soil seed bank. So, the results clearly showed that the common species between the soil seed bank and vegetation decreased with disturbance intensity. 

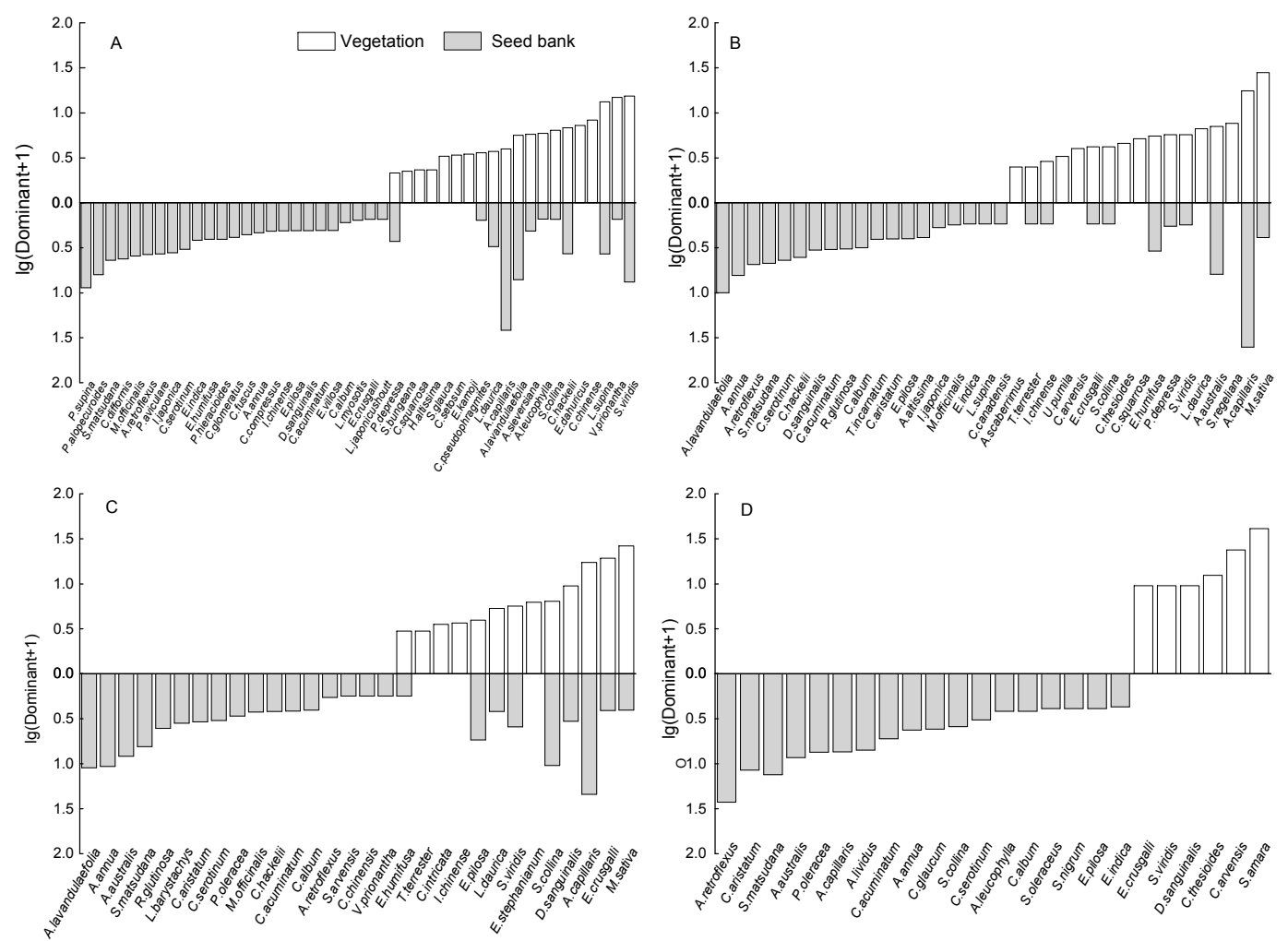

Figure 2. Comparison of the dominance of the species between soil seed bank and its established vegetation. (A) Native grassland; (B) Abandoned artificial grassland; (C) Artificial grassland; (D) Farmland.

\section{Discussion}

\subsection{Effects of Disturbance on Soil Seed Bank and Vegetation}

Our results showed that soil seed density and species richness in the four land use types were native grassland $>$ abandoned artificial grassland $>$ artificial grassland $>$ farmland, implying that the soil seed bank decreased with disturbance intensity. These results agreed with the results obtained from other arid or semi-arid climate regions. For example, Zabinski et al. [34] reported that the soil seed density significantly decreased in a severely disturbed (by camping) subalpine ecosystem in Montana, USA. Li et al. [35] found that the soil seed density of grassland decreased with increasing degradation intensity in Tibet, China. Navie et al. [36] found a decrease in soil seed density at very high levels of grazing, and an increase in soil seed density at intermediate levels of grazing in Queensland, Australia. Kinloch and Friedel [24] also reported that the heavy grazing over several decades reduced the soil seed bank, but light grazing had almost no effects on the soil seed bank in Australia. Our results are quite reasonable, because it has been reported that soil seed density and species richness are closely correlated with species composition and seed dispersal of aboveground vegetation [37]. In this study, the planting and harvesting of alfalfa in the artificial grassland limited the growth of other species, and the subsequent seed production. Similarly, the agricultural practices in the farmland, including deep ploughing, weeding, and herbicide application, greatly reduced the species richness of aboveground vegetation and the number of soil seed species besides the crops. Soil seed density in the abandoned artificial grassland and artificial grassland was $53.6 \%$ and $28.2 \%$ of the native grassland; species richness in the abandoned artificial grassland and the artificial grassland was $75.0 \%$ and $70.0 \%$ compared with the native grassland. These results indicated that there still are enough seeds and species for restoration in light and moderate human disturbance. On the basis of substituting space for time, after the abandonment of alfalfa grassland for eight years, the seed density in the abandoned artificial grassland increased $117.9 \%$, the species number of the soil seed bank 
increased $10.3 \%$, and the species number of the vegetation increased $21.4 \%$ compared with the alfalfa grassland. So, it is feasible to use the soil seed bank to restore the vegetation. Wen et al. [38] researched the land degradation and restoration in different land use types, and the result indicated that after fields were abandoned, vegetation self-restored, and plant species composition moved toward that of the natural grassland community with time. Van Hall et al. [39] found that the soil quality increased after abandonment in the form of elements such as carbon and nitrogen, which improved seed germination and vegetation growth, and made more seeds disperse into the soil. So, we could improve the soil quality in the process of vegetation restoration using the soil seed bank. However, although farmland was historically native grassland, after a long period of disturbance, the vegetation had moved far away from the original succession, and the seed density, species richness, and common species in the soil seed bank of native grassland had decreased rapidly. So, it is difficult to restore vegetation only by a natural soil seed bank. Thus, it is necessary to artificially add soil seeds or transplant artificial plants in this situation. Li et al. [35] found that for the grassland, there was not enough seeds in the soil seed bank, and the similarity between the soil seed bank and vegetation was very low. As a result, it was useful to plant pioneer species in order to accelerate vegetation restoration.

The species composition of the vegetation changed with the change of land use style. Species richness reduced with disturbance intensity. Practices such as the planting, harvesting, and weeding of the vegetation are the main reasons for the decrease in vegetation species [40]. Harvesting and weeding both reduced the seed production. So, the seeds that had fallen to the soil and the seed germination both reduced.

In this study, we also found that the seed bank in the upper soil layer was mostly significant higher than that in the deeper soil layer in the native grassland, abandoned artificial grassland, and artificial grassland, which was consistent with many other studies (e.g., [41,42]). However, there was no significant differences in the soil seed bank between the upper and deeper soil layers in the farmland (with severe disturbance) due to its frequent and deep ploughing [43], which indicated that the severe disturbance totally changed the vertical distribution of the soil seed bank besides its composition.

\subsection{Relationship between Soil Seed Bank and Vegetation}

We found that the soil seed bank and vegetation exhibited similar trends with human disturbance intensity in this study. Compared with the native grassland, the other three land use types had decreased soil seed density, species richness, and common species, both in the soil seed bank and vegetation. Olano et al. [44] considered that the soil seed bank was primarily supplied by the dispersal of seeds from the aboveground vegetation, and in turn it was the seedling resources of the development and succession of aboveground vegetation. Thus, the soil seed bank and vegetation were originally closely correlated with each other [45]. The fate of the vegetation determined the fate of the soil seed bank. Cerdà [46] found that the vegetation distribution determined the position of seeds. In sparse vegetation, the soil eroded, and the seeds were lacking or did not germinate. As a result, the seeds did not participate in the rehabilitation of the vegetation, which finally changed the vegetation composition. Although the soil seed bank and the vegetation were closely correlated with each other, the composition of vegetation was greatly different from that of the soil seed bank in this study, possibly due to the following three reasons. First, the proportion of annuals and perennials differed in the soil seed bank and the vegetation. These differences possibly resulted in a low similarity between the soil seed bank and the vegetation. Also, it was generally reported that it was common for perennials to be lacking in the soil seed bank, which meant less common species between the soil seed bank and the vegetation [47]. Thus, the exclusive species in the soil seed bank or vegetation increased the dissimilarity between the soil seed bank and the vegetation [48]. Second, a lot of the seeds (species) in the soil of the seed bank possibly failed to germinate during the germination experiments due to the differences in environment conditions between the greenhouse and the field. Third, a different dispersal pattern leads to species differences between the soil seed bank and the 
vegetation. For example, Salix matsudana existed in the soil seed bank, but was not found in vegetation. This was because the seeds were spread by the wind, and can be spread far away their mother plant. No common species were found in the farmland: due to manual weed control and herbicide usage, many plants in the vegetation were removed before our investigation of the vegetation.

\section{Conclusions}

Our results showed that seed density and species all decreased with as human disturbance intensity in the soil seed bank increased. Common species between the soil seed bank and vegetation also decreased as disturbance intensity increased. There were still many seeds and species in artificial grassland and abandoned artificial grassland for the restoration, but the seeds and species in farmland had reduced significantly. In conclusion, human disturbance would generate significant negative effects on the soil seed bank in desertified regions in a semi-arid climate. However, the soil seed bank in a land use type with light or moderate disturbance is still sufficient for vegetation restoration compared with that land use type with severe disturbance. The results would be helpful for vegetation restoration and desertification control in semi-arid regions of northern China, and similar regions all over the world.

Acknowledgments: This study was funded by the Young Project from Beijing Academy of Agriculture and Forestry Sciences (201627), the National Natural Science Foundation of China (31370540) and the Project for Innovation Construction from Beijing Academy of Agriculture and Forestry Sciences (KJCX20161502-1).

Author Contributions: Q.W. and B.X. conceived and designed the experiments; C.L. performed the experiments; C.L. and J.W. analyzed the data; R.Z. contributed reagents/materials/analysis tools; C.L. wrote the paper.

Conflicts of Interest: The authors declare no conflict of interest. 


\section{Appendix A}

Table A1. Species Name and Mean Density of Species Recorded in the Soil Seed Bank (Seed $\mathrm{m}^{-2}$ ) and the Vegetation (Number of Individuals $\mathrm{m}^{-2}$ ) in the Four Land Use Types.

\begin{tabular}{|c|c|c|c|c|c|c|c|c|c|c|}
\hline \multirow[b]{2}{*}{ Family } & \multirow[b]{2}{*}{ Species Name } & \multirow[b]{2}{*}{ Life Style } & \multicolumn{4}{|c|}{ Mean Number of Seeds $/ \mathrm{m}^{-2}$} & \multicolumn{4}{|c|}{ Mean Plants $/ \mathrm{m}^{-2}$} \\
\hline & & & $\begin{array}{c}\text { Native } \\
\text { Grassland }\end{array}$ & $\begin{array}{l}\text { Abandoned } \\
\text { Artificial } \\
\text { Grassland }\end{array}$ & $\begin{array}{l}\text { Artificial } \\
\text { Grassland }\end{array}$ & Farmland & $\begin{array}{c}\text { Native } \\
\text { Grassland }\end{array}$ & $\begin{array}{l}\text { Abandoned } \\
\text { Artificial } \\
\text { Grassland }\end{array}$ & $\begin{array}{l}\text { Artificial } \\
\text { Grassland }\end{array}$ & Farmland \\
\hline \multirow{3}{*}{ Amaranthaceae } & Amaranthus lividus & A & & & & 106 & & & & \\
\hline & Amaranthus retroflexus & A & 170 & 50 & 8 & 434 & & & & \\
\hline & Chenopodium acuminatum & A & 8 & 30 & 12 & 12 & & & & \\
\hline \multirow{2}{*}{ Asclepiadaceae } & Cynanchum chinense & $P$ & & & & & 18 & & & \\
\hline & Cynanchum thesioides & $\mathrm{P}$ & & & & & & 4 & & 2 \\
\hline Boraginaceae & Lappula myosotis & $\mathrm{A} / \mathrm{B}$ & 14 & & & & & & & \\
\hline \multirow{5}{*}{ Chenopodiaceae } & Chenopodium album & A & 36 & 12 & 8 & 8 & & & & \\
\hline & Chenopodium aristatum & A & & 18 & 20 & 128 & & & & \\
\hline & Chenopodium glaucum & A & & & & 14 & & & & \\
\hline & Chenopodium serotinum & A & 70 & 72 & 12 & 22 & & & & \\
\hline & Salsola collina & A & 6 & 4 & 412 & 8 & 21 & 2 & 4 & \\
\hline \multirow{13}{*}{ Compositae } & Artemisia аппиа & A & 144 & 236 & 386 & 16 & & & & \\
\hline & Artemisia capillaris & $\mathrm{P}$ & 4968 & 4232 & 1080 & 58 & 8 & 42 & 49 & \\
\hline & Artemisia lavandulaefolia & $\mathrm{P}$ & 808 & 656 & 496 & & 14 & & & \\
\hline & Artemisia leucophylla & $\mathrm{P}$ & 4 & & & 8 & 6 & & & \\
\hline & Artemisia sieversiana & $\mathrm{A} / \mathrm{B}$ & 124 & & & & 25 & & & \\
\hline & Cirsium setosum & $\mathrm{P}$ & & & & & 2 & & & \\
\hline & Conyza canadensis & A & & 4 & & & & & & \\
\hline & Inula japonica & $\mathrm{P}$ & 246 & 24 & & & & & & \\
\hline & Ixeridium chinense & $\mathrm{P}$ & 14 & 4 & & & & & 6 & \\
\hline & Picris hieracioides & $\mathrm{A} / \mathrm{B}$ & 16 & & & & & & & \\
\hline & Saussurea amara & $\mathrm{P}$ & & & & & & & & 6 \\
\hline & Sonchus arvensis & $\mathrm{P}$ & & & 4 & & & & & \\
\hline & Sonchus oleraceus & $\mathrm{A} / \mathrm{B}$ & & & & 4 & & 2 & & \\
\hline \multirow{2}{*}{ Convolvulaceae } & Cuscuta chinensis & A & & & 4 & & & & & \\
\hline & Convolvulus arvensis & $\mathrm{P}$ & & & & & & 2 & & 3 \\
\hline \multirow{4}{*}{ Cyperaceae } & Cyperus compressus & A & 18 & & & & & & & \\
\hline & Cyperus difformis & A & 158 & & & & & & & \\
\hline & Cyperus fuscus & A & 60 & & & & & & & \\
\hline & Cyperus glomeratus & A & 204 & & & & & & & \\
\hline \multirow{2}{*}{ Euphorbiaceae } & Acalypha australis & A & & 216 & 232 & 84 & & 14 & & \\
\hline & Euphorbia humifusa & A & 16 & 44 & 4 & & & 2 & 2 & \\
\hline Fabaceae & Trifolium incarnatum & A & & 22 & & & & & & \\
\hline
\end{tabular}


Table A1. Cont.

\begin{tabular}{|c|c|c|c|c|c|c|c|c|c|c|}
\hline \multirow[b]{2}{*}{ Family } & \multirow[b]{2}{*}{ Species Name } & \multirow[b]{2}{*}{ Life Style } & \multicolumn{4}{|c|}{ Mean Number of Seeds $/ \mathrm{m}^{-2}$} & \multicolumn{4}{|c|}{ Mean Plants/m $\mathbf{m}^{-2}$} \\
\hline & & & $\begin{array}{c}\text { Native } \\
\text { Grassland }\end{array}$ & $\begin{array}{c}\text { Abandoned } \\
\text { Artificial } \\
\text { Grassland }\end{array}$ & $\begin{array}{l}\text { Artificial } \\
\text { Grassland }\end{array}$ & Farmland & $\begin{array}{l}\text { Native } \\
\text { Grassland }\end{array}$ & $\begin{array}{c}\text { Abandoned } \\
\text { Artificial } \\
\text { Grassland }\end{array}$ & $\begin{array}{l}\text { Artificial } \\
\text { Grassland }\end{array}$ & Farmland \\
\hline Geraniaceae & Erodium stephanianum & $P$ & & & & & & & 3 & \\
\hline \multirow{16}{*}{ Gramineae } & Calamagrostis epigeios & $P$ & 14 & & & & 14 & & & \\
\hline & Cleistogenes squarrosa & $\mathrm{P}$ & & & & & 25 & 6 & & \\
\hline & Cleistogenes hackelii & $\mathrm{P}$ & 44 & 36 & 14 & & 2 & & & \\
\hline & Digitaria sanguinalis & A & 10 & 36 & 16 & & & & 13 & 1 \\
\hline & Echinochloa crusgalli & A & 6 & 4 & 10 & & & 2 & 60 & 1 \\
\hline & Elymus dahuricus & $\mathrm{P}$ & & & & & 29 & & & \\
\hline & Elymus kamoji & $\mathrm{P}$ & & & & & 3 & & & \\
\hline & Eleusine indica & A & 28 & 4 & & 2 & & & & \\
\hline & Eragrostis pilosa & A & 10 & 16 & 58 & 4 & & & 8 & \\
\hline & Eriochloa villosa & A & 8 & & & & & & & \\
\hline & Hemarthria altissima & $\mathrm{P}$ & & & & & 2 & & & \\
\hline & Lysimachia barystachys & $\mathrm{P}$ & & & 26 & & & & & \\
\hline & Pennisetum alopecuroides & $\mathrm{P}$ & 730 & & & & & & & \\
\hline & Setaria viridis & A & 908 & 8 & 48 & & 85 & 9 & 9 & 1 \\
\hline & Setaria glauca & A & & & & & 2 & & & \\
\hline & Stipa bungeana & $\mathrm{P}$ & & & & & 2 & & & \\
\hline \multirow{3}{*}{ Labiatae } & Lagopsis supina & $\mathrm{P}$ & 268 & 4 & & & 95 & & & \\
\hline & Leonurus japonicushoutt & $\mathrm{A} / \mathrm{B}$ & 6 & & & & & & & \\
\hline & Scutellaria regeliana & $\mathrm{P}$ & & & & & & 17 & & \\
\hline \multirow{4}{*}{ Leguminosae } & Astragalus scaberrimus & A & & & & & & 1 & & \\
\hline & Lespedeza daurica & $\mathrm{P}$ & 18 & & 14 & & 6 & 7 & 16 & \\
\hline & Medicago sativa & $\mathrm{P}$ & & 8 & 8 & & & 91 & 110 & \\
\hline & Melilotus officinalis & $\mathrm{A} / \mathrm{B}$ & 98 & 8 & 16 & & & & & \\
\hline Plantaginaceae & Plantago depressa & $\mathrm{A} / \mathrm{B}$ & 44 & 16 & & & 1 & 3 & & \\
\hline \multirow[t]{2}{*}{ Polygonaceae } & Polygonum aviculare & $\mathrm{A}$ & 270 & & & & & & & \\
\hline & Portulaca oleracea & A & & & 34 & 60 & & & & \\
\hline Ranunculaceae & Clematis intricata & $P$ & & & & & & & 6 & \\
\hline Rosaceae & Potentilla supina & $\mathrm{A} / \mathrm{B}$ & 1280 & & & & & & & \\
\hline Salicaceae & Salix matsudana & $P$ & 192 & 112 & 122 & 132 & & & & \\
\hline Scrophulariaceae & Rehmannia glutinosa & $P$ & & 24 & 58 & & & & & \\
\hline Simaroubaceae & Ailanthus altissima & $P$ & & 8 & & & & & & \\
\hline Solanaceae & Solanum nigrum & A & & & & 4 & & & & \\
\hline Ulmaceae & Ulmus pumila & $\mathrm{P}$ & & & & & & 4 & & \\
\hline Violaceae & Viola prionantha & $P$ & 6 & & 4 & & 110 & & & \\
\hline Zygophyllaceae & Tribulus terrester & A & & 4 & & & & 1 & 2 & \\
\hline
\end{tabular}

A: Annuals; B: Biennial; P: Perennials. 


\section{References}

1. Strait, G.C. Facing desertification. World I 2000, 15, 140-147.

2. Reynolds, J.F.; Smith, D.M.S.; Lambin, E.F.; Turner, B.L.; Mortimore, M.; Batterbury, S.P.J.; Downing, T.E.; Dowlatabadi, H.; Fernández, R.J.; Herrick, J.E.; et al. Global desertification: Building a science for dryland development. Science 2007, 316, 847-851. [CrossRef] [PubMed]

3. United Nations Convention to Combat Desertification. Desertification: A Visual Synthesis; UNCCD Secretariat: Bonn, Germany, 2011.

4. Wang, G.Q.; Wang, X.Q.; Wu, B.; Lu, Q. Desertification and its mitigation strategy in China. J. Resour. Ecol. 2012, 3, 97-104.

5. State Forestry Administration of China. A Bulletin of Status Quo of Desertification and Sandification in China; State Forestry Administration of China: Beijing, China, 2011. (In Chinese)

6. Pensa, M.; Sellin, A.; Luud, A.; Valgma, I. An analysis of vegetation restoration on opencast oil shale mines in Estonia. Restor. Ecol. 2004, 12, 200-206. [CrossRef]

7. Cao, S.X. Why large-scale afforestation efforts in China have failed to solve the desertification problem. Environ. Sci. Technol. 2008, 42, 1826-1831. [CrossRef] [PubMed]

8. Keesstra, S.; Nunes, J.; Novara, A.; Finger, D.; Avelar, D.; Kalantari, Z.; Cerdà, A. The superior effect of nature based solutions in land management for enhancing ecosystem services. Sci. Total Environ. 2018, 610, 997-1009. [CrossRef] [PubMed]

9. Nishihiro, J.; Nishihiro, M.A.; Washitani, I. Restoration of wetland vegetation using soil seed banks: Lessons from a project in Lake Kasumigaura, Japan. Landsc. Ecol. Eng. 2006, 2, 171-176. [CrossRef]

10. Luzuriaga, A.L.; Escudero, A.; Olano, J.M.; Loidi, J. Regenerative role of seed banks following an intense soil disturbance. Acta Oecol. 2005, 27, 57-66. [CrossRef]

11. Walck, J.L.; Baskin, J.M.; Baskin, C.C.; Hidayati, S.N. Defining transient and persistent seed banks in species with pronounced seasonal dormancy and germination patterns. Seed Sci. Res. 2005, 15, 189-196. [CrossRef]

12. Fisher, J.L.; Loneragan, W.A.; Dixon, K.; Veneklaas, E.J. Soil seed bank compositional change constrains biodiversity in an invaded species-rich woodland. Biol. Conserv. 2009, 142, 256-269. [CrossRef]

13. Jalili, A.; Hamzeh'ee, B.; Asri, Y.; Shirvany, A.; Yazdani, S.; Khoshnevis, M.; Zarrinkamar, F.; Ghahramani, M.-A.; Safavi, R.; Shaw, S. Soil seed banks in the arasbaran protected area of Iran and their significance for conservation management. Biol. Conserv. 2003, 109, 425-431. [CrossRef]

14. Zhan, X.; Li, L.; Cheng, W. Restoration of stipa kryloviisteppes in Inner Mongolia of China: Assesment of seed banks and vegetation composition. J. Arid Environ. 2007, 68, 298-307. [CrossRef]

15. Williams, L.; Reich, P.; Capon, S.J.; Raulings, E. Soil seed banks of degraded riparian zones in southeastern Australia and their potential contribution to the restoration of understorey vegetation. River Res. Appl. 2008, 24, 1002-1017. [CrossRef]

16. Duncan, R.P.; Diez, J.M.; Sullivan, J.J.; Wangen, S.; Miller, A.L. Safe sites, seed supply, and the recruitment function in plant populations. Ecology 2009, 90, 2129-2138. [CrossRef] [PubMed]

17. Liu, M.Z.; Jiang, G.M.; Yu, S.L.; Li, Y.G.; Li, G. The role of soil seed banks in natural restoration of the degraded hunshandak sandlands, northern China. Restor. Ecol. 2009, 17, 127-136. [CrossRef]

18. Valkó, O.; Török, P.; Tóthmérész, B.; Matus, G. Restoration potential in seed banks of acidic fen and dry-mesophilous meadows: Can restoration be based on local seed banks? Restor. Ecol. 2011, 19, 9-15. [CrossRef]

19. Cerdà, A.; García-Fayos, P. The influence of seed size and shape on their removal by water erosion. Catena 2002, 48, 293-301. [CrossRef]

20. Sanderson, M.A.; Stout, R.; Goslee, S.; Gonet, J.; Smith, R.G. Soil seed bank community structure of pastures and hayfields on an organic farm. Can. J. Plant Sci. 2014, 94, 621-631. [CrossRef]

21. Gomaa, N.H. Soil seed bank in different habitats of the eastern desert of Egypt. Saudi J. Biol. Sci. 2012, 19, 211-220. [CrossRef] [PubMed]

22. Amrein, D.; Rusterholz, H.P.; Baur, B. Disturbance of suburban Fagus forests by recreational activities: Effects on soil characteristics, above-ground vegetation and seed bank. Appl. Veg. Sci. 2005, 8, 175-182. [CrossRef]

23. Mayor, M.D.; Bóo, R.M.; Peláez, D.V.; Elía, O.R. Seasonal variation of the soil seed bank of grasses in central Argentina as related to grazing and shrub cover. J. Arid Environ. 2003, 53, 467-477. [CrossRef] 
24. Kinloch, J.E.; Friedel, M.H. Soil seed reserves in arid grazing lands of central Australia. Part 1: Seed bank and vegetation dynamics. J. Arid Environ. 2005, 60, 133-161.

25. Karlík, P.; Poschlod, P. Soil seed-bank composition reveals the land-use history of calcareous grasslands. Acta Oecol. 2014, 58, 22-34. [CrossRef]

26. Zeiter, M.; Preukschas, J.; Stampfli, A. Seed availability in hay meadows: Land-use intensification promotes seed rain but not the persistent seed bank. Agric. Ecosyst. Environ. 2014, 182, 88-95. [CrossRef]

27. Tefera, S.B. Soil seed bank dynamics in relation to land management and soil types in the semi-arid savannas of Swaziland. Afr. J. Agric. Res. 2011, 6, 2494-2505.

28. Pol, R.G.; Sagario, M.C.; Marone, L. Grazing impact on desert plants and soil seed banks: Implications for seed-eating animals. Acta Oecol. 2014, 55, 58-65. [CrossRef]

29. Bueno, C.G.; Reiné, R.; Alados, C.L.; Gómez-García, D. Effects of large wild boar disturbances on alpine soil seed banks. Basic Appl. Ecol. 2011, 12, 125-133. [CrossRef]

30. Ma, M.J.; Zhou, X.H.; Du, G.Z. Role of soil seed bank along a disturbance gradient in an alpine meadow on the Tibet plateau. Flora 2010, 205, 128-134. [CrossRef]

31. Tessema, Z.K.; de Boer, W.F.; Baars, R.M.T.; Prins, H.H.T. Influence of grazing on soil seed banks determines the restoration potential of aboveground vegetation in a semi-arid savanna of Ethiopia. Biotropica 2012, 44, 211-219. [CrossRef]

32. Wang, X.L.; Yang, S.T.; Mannaerts, C.M.; Gao, Y.F.; Guo, J.X. Spatially explicit estimation of soil denitrification rates and land use effects in the riparian buffer zone of the large Guanting reservoir. Geoderma 2009, 150, $240-252$. [CrossRef]

33. Thompson, K.; Grime, J.P. Seasonal variation in the seed banks of herbaceous species in ten contrasting habitats. J. Ecol. 1979, 67, 893-921. [CrossRef]

34. Zabinski, C.; Wojtowicz, T.; Cole, D. The effects of recreation disturbance on subalpine seed banks in the rocky mountains of Montana. Can. J. Bot. 2000, 78, 577-582.

35. Li, Y.Y.; Dong, S.K.; Wen, L.; Wang, X.X.; Wu, Y. Soil seed banks in degraded and revegetated grasslands in the alpine region of the Qinghai-Tibetan plateau. Ecol. Eng. 2012, 49, 77-83. [CrossRef]

36. Navie, S.C.; Cowley, R.A.; Rogers, R.W. The relationship between distance from water and the soil seed bank in a grazed semi-arid subtropical rangeland. Aust. J. Bot. 1996, 44, 421-431. [CrossRef]

37. Gomaa, N.H. Microhabitat variations and seed bank-vegetation relationships in a desert wadi ecosystem. Flora 2014, 209, 725-732. [CrossRef]

38. Wen, Z.Z.; Hong, L.X.; Zhi, M.L.; Jin, L. Soil degradation and restoration as affected by land use change in the semiarid bashang area, northern China. Catena 2005, 59, 173-186.

39. Van Hall, R.L.; Cammeraat, L.H.; Keesstra, S.D.; Zorn, M. Impact of secondary vegetation succession on soil quality in a humid Mediterranean landscape. Catena 2017, 149, 836-843. [CrossRef]

40. Mitlacher, K.; Poschlod, P.; Rosén, E.; Bakker, J.P. Restoration of wooded meadows-A comparative analysis along a chronosequence on land (Sweden). Appl. Veg. Sci. 2002, 5, 63-73.

41. Albrecht, H.; Eder, E.; Langbehn, T.; Tschiersch, C. The soil seed bank and its relationship to the established vegetation in urban wastelands. Landsc. Urban Plan. 2011, 100, 87-97. [CrossRef]

42. Klug-Pümpel, B.; Scharfetter-Lehrl, G. Soil diaspore reserves above the timberline in the Austrian Alps. Flora 2008, 203, 292-303. [CrossRef]

43. Swanton, C.J.; Shrestha, A.; Knezevic, S.Z.; Roy, R.C.; Ball-Coelho, B.R. Influence of tillage type on vertical weed seedbank distribution in a sandy soil. Can. J. Plant Sci. 2000, 80, 455-457. [CrossRef]

44. Olano, J.M.; Caballero, I.; Escudero, A. Soil seed bank recovery occurs more rapidly than expected in semi-arid mediterranean gypsum vegetation. Ann. Bot. 2012, 109, 299-307. [CrossRef] [PubMed]

45. López-Mariño, A.; Luis-Calabuig, E.; Fillat, F.; Bermúdez, F.F. Floristic composition of established vegetation and the soil seed bank in pasture communities under different traditional management regimes. Agric. Ecosyst. Environ. 2000, 78, 273-282. [CrossRef]

46. Cerdà, A. The Effect of Patchy Distribution of Stipa Tenacissima L. on Runoff and Erosion. J. Arid Environ. $1997,36,37-51$. 
47. Navarra, J.J.; Quintana-Ascencio, P.F. Spatial pattern and composition of the Florida scrub seed bank and vegetation along an anthropogenic disturbance gradient. Appl. Veg. Sci. 2012, 15, 349-358. [CrossRef]

48. Amiaud, B.; Touzard, B. The relationships between soil seed bank, aboveground vegetation and disturbances in old embanked marshlands of western France. Flora 2004, 199, 25-35. [CrossRef]

(C) 2017 by the authors. Licensee MDPI, Basel, Switzerland. This article is an open access article distributed under the terms and conditions of the Creative Commons Attribution (CC BY) license (http:/ / creativecommons.org/licenses/by/4.0/). 